\title{
Carborane Acid: Protonation of the Weakest Bases by the Strongest Acid
}

Eiji Tsurumaki

Carborane acid is the strongest Brönsted acid presently known, possessing unusually high acidity greater than fluorosulfuric acid. Protonation by a carborane acid have proceeded effectively towards the weakest bases such as benzene, fullerene, alkanes, and even carbon dioxide, producing corresponding reactive cations as salts with the least coordinating carborane anion. This short-review highlights recent reports on structural elucidations of several important cations using a carborane acid.

有機化学者であれば誰もが, 初等教育においてカルボ カチオンについて学ぶだろう。カルボカチオンは主に酸 性条件における置換反応 $\left(\mathrm{S}_{\mathrm{N}} 1\right)$ や脱離反応 $(\mathrm{E} 1)$, 芳香族 求電子置換反応 $\left(\mathrm{S}_{\mathrm{E}} \mathrm{Ar}\right)$ といった反応の中間体とされて おり, カルボカチオンの安定性や反応性を考えること で, 反応の位置選択性や反応機構をおおむね理解するこ とができる。このように, カルボカチオンは有機化学に おいて重要な化学種であるが，一般に活性な化学種であ るため，安定な形で捕捉したり単離したりすることは一 筋縄ではいかない。

カルボカチオンの不安定性は, その高い求電子性ゆえ に求核剤や塩基と容易に反応することに由来する。そこ で，求核性の低い安定アニオンを対アニオンとして用い ることでカルボカチオンの安定化を図ることができ る1)。安定アニオンの共役酸はすなわち強力な酸である から，より強力な酸を用いることでカルボカチオンのよ り効率的な生成と安定化が期待できる。では, 現存で最 も強い酸は一体どのような酸で, どのような不安定カチ オンの生成および安定化が可能だろうか。本稿では, Reed らによって発見された，単一成分の酸の中で最強 の酸であるカルボラン酸の化学を紹介する。

\section{1. カルボラン酸とは}

カルボランは炭素とホウ素からなるクラスターを指 し，本稿で取り上げるホウ素 11 個と炭素 1 個からなる クロソ型クラスターであるモノカルバドデカボラン $\left[\mathrm{CHB}_{11} \mathrm{R}_{11}\right]^{-}$もその 1 つである。モノカルバドデカボラ ンは 1 価のアニオンであるが, クラスター全体で負電荷 を非局在化するため, 配位性が非常に低いアニオンであ る。また, 腐食性がなく, 結晶性, 安定性ともに高いこ とから, 種々の不安定カチオンを安定に得るための対ア ニオンとして適したアニオンである2)。本稿では以下, モノカルバドデカボランを単にカルボランと呼ぶ。
Reedらは, カルボランのセシウム塩から始まり, 銀塩, トリチル塩, トリエチルシリリウム塩へと段階的にカチ オン交換を行い，最終的に塩化水素との反応によりプロ トンを対カチオンに持つカルボラン酸へ導いた(スキー ム 1)。カルボラン酸は標準状態で固体酸であるため, 酸性度の指標としてよく用いられるハメット酸性度 $H_{0}$ を直接決定することはできないが, 種々の分光測定や弱 塩基との反応性を検証することで間接的に酸性度が見積 もられた。その結果, カルボラン酸の発見まで単独分子 のなかで最強の酸とされていたフルオロスルホン酸より も高い酸性度を有することが確認された ${ }^{3)}$ 。また, カル ボランのホウ素上にハロゲン置換基を導入することで, カルボラン酸の酸性度をさらに高めることが可能であ り，ホウ素上を徹底フッ素化した $\mathrm{H}\left[\mathrm{CHB}_{11} \mathrm{~F}_{11}\right]$ がカル ボラン酸のなかでも最も高い酸性度を示す, 単一成分の 酸のなかで現存最強の酸である ${ }^{4 a)} 。$

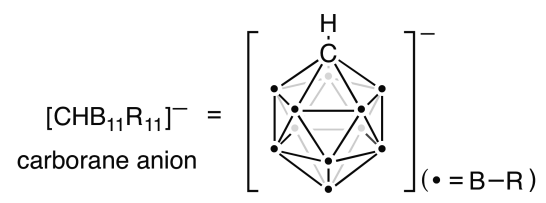

$\mathrm{Cs}\left[\mathrm{CHB}_{11} \mathrm{R}_{11}\right] \underset{-\mathrm{CsNO}_{3}}{\stackrel{\mathrm{AgNO}_{3}}{\longrightarrow}} \mathrm{Ag}\left[\mathrm{CHB}_{11} \mathrm{R}_{11}\right] \underset{-\mathrm{AgBr}}{\stackrel{\mathrm{Ph}_{3} \mathrm{CBr}}{\longrightarrow}}\left[\mathrm{Ph}_{3} \mathrm{C}\right]\left[\mathrm{CHB}_{11} \mathrm{R}_{11}\right]$

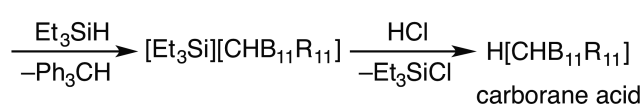

Scheme 1 Schematic structure of a carborane anion $\left[\mathrm{CHB}_{11} \mathrm{R}_{11}\right]^{-}$and synthesis of a carborane acid H$\left[\mathrm{CHB}_{11} \mathrm{R}\right]$.

\section{2. カルボラン酸を用いる不安定カチオンの合成と構造} 解析

カルボラン酸の反応性を見てみよう(スキーム 2)。カ ルボラン酸は非常に強力な酸であるため, 一般に不活性 とされる非常に弱い塩基でも容易にプロトン化する。例 
えば, カルボラン酸をベンゼンに溶解すると, 速やかに ベンゼンのプロトン化が進行し, ベンゼニウムイオン塩 が得られた ${ }^{5)}$ 。このカチオンの構造は, 芳香族求電子置 換反応のアレーニウムイオン中間体 (Wheland 中間体)に 相当し，有機化学において重要な化学種である。Reed らは, この塩の結晶構造解析に成功し, プロトンが付加 した炭素が確かに $\mathrm{sp}^{3}$ 混成となっており, ベンゼンに比 べて炭素-炭素結合長が伸長することを確認した。

球状の芳香族化合物であるフラーレンとカルボラン酸 の反応も速やかに進行し, $\left[\mathrm{C}_{60} \mathrm{H}\right]^{+}$のカルボラン塩を与 えた ${ }^{6)}$ 。その ${ }^{13} \mathrm{C} \mathrm{NMR}$ スペクトルは低温条件下におい てもピークの分裂を示さず, 中性のフラーレンの ${ }^{13} \mathrm{C} シ$ グナルに比べて低磁場シフトしつつも 1 本の一重線を示 した。これはすなわち, フラーレン上のプロトンは, 低 温条件下においても NMRの時間尺度より早い速度で 1,2-プロトン移動を繰り返し，球状表面で激しく動き 回っていることを示唆している。

カルボラン酸をもってすれば，単純なアルカンさえも 塩基として働く。合成されたカルボラン酸のなかで最も 強い酸性度を示す $\mathrm{H}\left[\mathrm{CHB}_{11} \mathrm{~F}_{11}\right]$ は液化 $n$-ブタンとも反 応し，ブタン中の水素をヒドリドとして引き抜き， $\mathrm{H}_{2}$ を放出するとともに炭素の転位を経て tert-ブチルカチ オンを与えた ${ }^{4 a)}$ te tert-ブチルカチオンはカルボランア ニオンとの塩として安定に単離され, 単結晶 X 線回折 測定も行われた ${ }^{4 \mathrm{~b})}$ 。安定で結晶性の高いカルボランアニ オンを用いることで高品質な単結晶の作成および解析が 可能となり, 結晶構造において tert-ブチルカチオン上 の水素の位置も決定された。結晶構造中の $\mathrm{C}-\mathrm{C}-\mathrm{H}$ 角を 調べると，そのうち 1 つが $101^{\circ}$ と，通常のメチル基よ り $10^{\circ}$ ほど小さい值を示しており, カルボカチオンを安 定化する超共役の存在が直接的に確認された。また同時 に, tert-ブチルカチオンとカルボランアニオンのハロ ゲン置換基との間に $\mathrm{C}-\mathrm{H} \cdots \mathrm{X}$ 型の水素結合が確認され, 凝縮系においては超共役と水素結合の両方がカルボカチ オンの安定化に重要であるとわかった。

さらに Reedらは, $\mathrm{H}\left[\mathrm{CHB}_{11} \mathrm{~F}_{11}\right]$ がどこまで弱い塩基

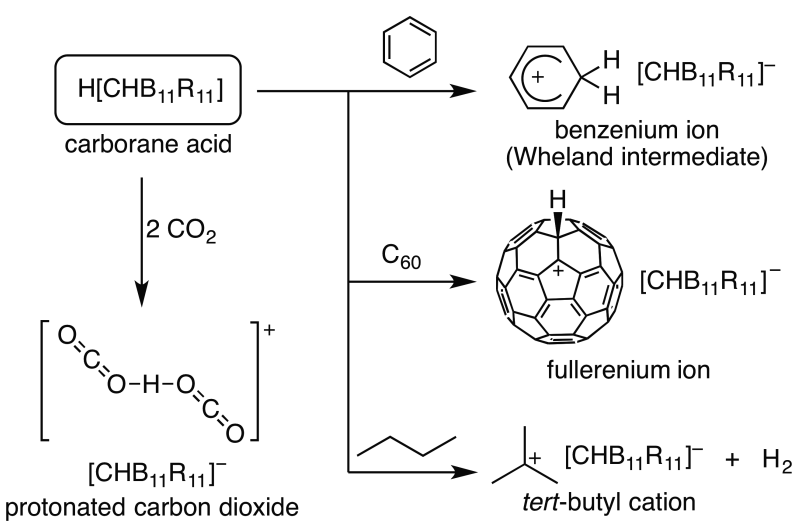

Scheme 2 Protonation of weak bases with a carborane acid.
までプロトン化できるか探索すべく, 最も弱い塩基の 1 つである二酸化炭素のプロトン化を試みた ${ }^{7)}$ 。固体状態 の $\mathrm{H}\left[\mathrm{CHB}_{11} \mathrm{~F}_{11}\right]$ に二酸化炭素を作用させることで，そ のプロトン化体の生成が IR スペクトルの測定により確 認された。IRの測定結果を量子化学計算によるカチオ ンの構造最適化および振動計算を基に解析することで, 2 分子の二酸化炭素がプロトンを介した低障壁水素結合 (low-barrier hydrogen bonding)により架橋された構造 のカチオン種が生成していることがわかった。このよう に二酸化炭素を円滑にプロトン化し, 生じるカチオン種 を凝縮系でも安定化するという反応性は, これまで最強 の酸であったマジック酸(フルオロスルホン酸/五フッ化 アンチモン混合溶液)でも認められないため, H$\left[\mathrm{CHB}_{11} \mathrm{~F}_{11}\right]$ は実用的にはマジック酸を超える最強の酸 であると Reedらは結論づけた。

\section{おわりに}

安定かつ配位性のそしいアニオンであるカルボランア ニオンを対アニオンに用いることで, 最も反応性の高い カチオンであるプロトンを最もフリーな形で安定化し， この塩を最も強力な酸として利用することが可能になっ た。カルボラン酸およびその類縁ルイス酸を未開拓なカ チオン種の探索や酸触媒反応などの有機合成に用いる試 みは広がりを見せており, 今後もさらなる発展が期待さ れる。

文献

1) G. A. Olah, G. K. S. Prakash, J. Sommer, Superacids, John Wiley \& Sons, Inc., New York, 1985

2) For recent reviews, see: (a)C. A. Reed, Chem. Commun., 2005, 1669; (b)C. A. Reed, Acc. Chem. Res., 43, 121(2010); (c) C. A. Reed, Acc. Chem. Res., 46, 2567 (2013)

3) M. Juhasz, S. Hoffmann, E. S. Stoyanov, K.-C. Kim, C. A. Reed, Angew. Chem. Int. Ed., 43, 5352(2004)

4) (a) M. Nava, I. V. Stoyanova, S. Cummings, E. S. Stoyanov, C. A. Reed, Angew. Chem. Int. Ed., 53, 1131(2014); (b)E. S. Stoyanov, I. V. Stoyanova, F. S. Tham, C. A. Reed, Angew. Chem. Int. Ed., 51, 9149 (2012)

5) C. A. Reed, N. L. P. Facklar, K.-C. Kim, D. Stasko, D. R. Evans, P. D. W. Boyd, C. E. F. Rickard, J. Am. Chem. Soc., 121, 6314 (1999)

6) C. A. Reed, K.-C. Kim, R. D. Bolsker, L. Mueller, Science, 289, 101 (2000)

7) S. Cummings, H. P. Hratchian, C. A. Reed, Angew. Chem. Int. Ed., 55, 1382(2016)

(2016 年 11 月 22 日受理)

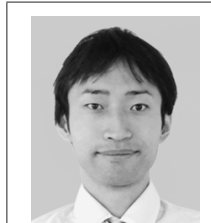

鶴巻英治 東京工業大学理学院化学系·助教 博 士 (理学)

〔所属研究室主宰者〕豊田真司

〔経歴〕2009-12 年日本学術振興会特別研究員 (DC1), 2013 年京都大学大学院理学研究科博士後 期課程修了 (指導教員 : 大須賀篤弘教授)，2014 年同博士研究員, 2015 年 11 月より現職。〔研究テーマ〕構造有機 化学, 芳香族化合物。〔連絡先〕 e-mail: tsurumaki@cms.titech.ac.jp 